\title{
Nematode-Larvae Infestation in Goats Fed "Malojillo" (Pará Grass) and Merker Grasses in Puerto Rico
}

\author{
H. Ciordia and J. D. Rivera-Anaya ${ }^{1}$
}

\section{. INTRODUCTION}

Internal parasitism of domestic animals in Puerto Rico is of great economic importance. High humidity, heavy rainfall, moderate temperature and a relatively dense animal population in a restricted area are among the ecological factors favorable for parasitism.

The prevalence of intestinal nematodes is perhaps one of the most important reasons why the goat population in Puerto Rico is low. Death of goats from parasitism is very common, and discourages farmers from increasing the number of animals and from importing exotic breeds. This limiting factor is very important to the economy of the Island because goats would be ideal milk animals for small farmers, sharecroppers, and in other cases in which available grazing land is limited. The parasite problem must be investigated further before any appreciable success is obtained in encouraging rural families to raise goats for milk and meat.

Although most of the detrimental effects of parasitism on the animals may be counteracted by proper care and feeding, the use of concentrates would not be feasible in Puerto Rico because of the poverty of most of the rural families. Therefore, grasses are almost entirely depended on to feed goats. "Malojillo", or Pará grass (Panicum purpurascens Raddi), is the most common, sometimes growing wild or uncultivated in a variety of habitats, but usually in moist low soils, riverbanks, marshes, and swamps. Merker grass (Pennisetum purpurascens va. merkerii Schumaker) is morphologically different from malojillo as to size of stems and blades, shape and number of leaves, degree of pubescense, height, erectness of growth, etc.

Previous larval counts were performed at the Animal Husbandry Department of this Agricultural Experiment Station on malojillo and Merker grasses from alternate, adjacent plots on low, wet ground between 1947 and 1950. A total of 78 larval counts was made on each grass, on 200 -gm. samples of chopped grass for each count using the Baermann technique. (3) $)^{2}$ Malojillo had an average count of 23.37 larvae per 200-gm. sample, whereas Merker grass had an average of only 3.13 larvae per sample. No

${ }^{1}$ Associate Parasitologist and Veterinarian, respectively, of the Agricultural Experiment Station, University of Puerto Rico, Río Piedras, P. R.

2 Numbers in parentheses refer to Literature Cited, p. 31. 
distinction between larvae of free-living and parasitic nematodes was attempted.

This experience induced the authors to investigate whether goats would acquire a significant variation in number and species of nematodes when fed these two grasses.

\section{MATERIALS AND METHODS}

The experimental goats were obtained from the Lajas Substation of the Puerto Rico Agricultural Experiment Station.

Pregnant females were scrubbed and placed in clean, concrete stalls prior to parturition. The kids were taken away from their dams immediately after delivery and placed in a specially constructed cage. The cage, measuring about $3^{\prime} \times 3^{\prime} \times 10^{\prime}$, had a wooden framework with welded, galvanized wire-fabric on all six sides to facilitate cleaning, was comfortable for the kids, and easily transportable. To protect the animals from the weather, the cage was placed under a tin roof and raised about 2 feet from the ground. To prevent infestation of the animals with intestinal parasites, the cage was placed about 1,000 yards from the goat herd and isolated from other domestic animals. No vegetation was allowed to come in contact with the cage, and it was maintained clean at all times.

Once isolated in the cage the kids were bottle-fed with goat's milk which was gradually supplemented with, concentrate. When about 3 months old they were brought to the main Station at Rio Piedras, where the experiments were conducted. As it turned out, the 12 kids were of different ages, with a variation of about 5 weeks between the oldest and the youngest. The male kids were castrated with an emasculator shortly afterwards and were fully recovered by the time the experiments started. Two of the animals died of accidental suffocation and, unfortunately, we were not able to replace them.

The kids were kept in part of a barn that provided sufficient isolation from other animals. This area was divided into three cages, walled-off by welded, galvanized wire-fabric with "calf-mat" floors supported about $11 / 2$ feet above the barn's concrete floor. The calf-mat floors had the least possible supports to prevent fecal pellets from lodging in the crevices, and were easily cleaned. Each cage, separated by 3 -foot passageways from' adjacent ones, was provided with a feeding box, designed to prevent the kids from getting into it and to make it easy to keep clean.

The young goats continued their milk diet, but the amount of concentrate was increased gradually. Imported hay was also provided. This feeding schedule was followed until the beginning of the experiments. Meanwhile, fecal samples were periodically examined to insure our dealing 
with parasite-free animals. A very light infestation with Strongyloides papillosus was detected in 4 of the 10 animals. This was not considered to be serious since the difficulty of preventing an infection with that nematode was well known (2). As a preventive measure, each goat received phenothiazine for a period of 4 days about 2 weeks before starting the experiments. Phenothiazine, although ineffective against $S$. papillosus, was used in the event of very light undetected infestation with other roundworms.

The 10 kids were divided into 2 groups of 4 animals each and a third one of 2. The animals of each group were placed in one of the cages previously described, where they remained for the duration of the experiment. One group of goats received chopped Merker grass (Pennisetum purpurascens va. merkerii Schumaker) and concentrate. The second group was fed chopped malojillo (Pará grass) (Panicum purpurascens Raddi) and concentrate. The third group received imported hay and concentrate, and thus served as a control group.

Merker and malojillo grasses freshly cut from adjacent plots, were given to the corresponding animals daily, cutting being done in the early morning, when the grass was still damp with dew. Either one of the two grasses was cut first and placed in a designated burlap sack to prevent contamination. The machete employed was wiped clean before the other grass was cut.

At the start of the experiment the two grasses studied were obtained from plots about a mile from where the animals were housed. However, since the animals were not being parasitized as heavily as desired, due to the low larval counts of these grasses; it was decided to out the grasses from a gulley that drained the feces and the water used in cleaning the barn. This apparently was a paradise for parasites. Here also the Merker and malojillo grasses grew side by side, and both the larval counts and the humidity were very high. The same care was exercised in cutting and transporting the grasses.

The daily routine in the care of the goats consisted of a thorough scrubbing and flushing of the cages and feedboxes, removal of the grass left over from the preceding day, washing and replenishing the drinking waterbuckets; and hosing the concrete floor of the barn thus dislodging any fecal pellets that might have caught in the calf-mat floor. The man who did this work was asked to remove his shoes before entering the cages, and to wash his feet before going into another cage. After the cages were properly cleaned fresh grass was placed in the feedbox.

Fecal samples collected from the rectum of each goat were examined weekly for about 1 month prior to the beginning of the experiments. Only 
Strongyloides papillosus ova were seen in 5 of the 10 animals. Egg counts were made by using the sugar-flotation method, where $1 \mathrm{gm}$. of fecal pellets was ground in a mortar, rinsed with sugar solution, and filtered through a sieve and into a centrifuge tube. The tube was capped with a cover glass, and centrifuged for 4 minutes, at 2,000 r.p.m. The cover glass was raised quickly from the centrifuge tube and placed on a slide. The total surface of the cover glass formerly in contact with the supernatant was searched for nematode ova. Thus, the total egg count per cover glass could be interpreted as the number of eggs per gram of feces. Egg counts were made every 15 days during the experimental period.

At the time the rectal fecal sample was obtained from each animal, a blood sample was drawn to determine its hemoglobin content and the packed-cell volume. The Sheard and Sanford method for hemoglobin determination was employed (1); packed-cell volumes were determined by the Wintrobe technique.

At the conclusion of the experiment all the goats were sacrificed and a meticulous search of the digestive tracts was made to recover all intestinal parasites. The technique for recovering the worms was closely followed in all the examinations so as to avoid discrepancies in the results due to variations in techniques.

Double ligatures secured with twine were tied on the esophagus near its entrance to the rumen, between the omasum and abomasum, at the pyloric area, at the ileocecal junction, and at the cecocolonic junction. A single ligature was tied far down on the rectum, near the anus. Cuts between each pair of double ligatures allowed separation of the gastrointestinal tract in tied-off sections without chance of spillage of their contents and loss of any parasites present.

Each tied-off section was individually slit open and its contents washed thoroughly through a sieve with a 40 -gage mesh using a sink hand-shower. Any nematodes present were retained by the mesh. Parasites recovered from each goat were placed in a suitable container with preservative and saved for future counting and identification. The mucosa was painstakingly searched for worms that were put in the corresponding vial for future counting and identification.

\section{OBSERVATIONS AND CONCLUSIONS}

The hemoglobin content of the blood samples from all the goats failed to demonstrate any significant variation from the normal curve (table 1). This lack of variation in blood hemoglobin among the three groups of animals receiving different grasses might be explained mainly by the low degree of parasitism achieved in all the animals and by the fact that the 
TABLE 1.-Hemoglobin content of blood taken at 15-day intervals from 10 differently fed goats, in Puerto Rico, 1953

\begin{tabular}{l|c|c|c|c|c|c|c|c}
\hline \multirow{2}{*}{ Group treatment } & Goat No. or name & \multicolumn{6}{|c}{ Grams of hemogiobin/100 mI, of blood,on- } \\
\cline { 2 - 7 } & & June 1 & June 16 & June 30 & July 13 & July 27 & Aug. 12 & Aug. 24 \\
\hline Group I, fed Merker & 1987 & 10.0 & 10.9 & 10.6 & 10.4 & 11.2 & 11.2 & 11.1 \\
& 1959 & 12.1 & 12.0 & 12.1 & 11.1 & 12.4 & 12.3 & 13.0 \\
& 1963 & 11.5 & 11.8 & 12.0 & 11.0 & 11.9 & 10.7 & 10.8 \\
& 1982 & 13.0 & 13.5 & 13.5 & 13.1 & 13.0 & 12.4 & 13.0 \\
Group II, fed malo- & 1942 & 12.7 & 11.6 & 12.2 & 12.3 & 12.1 & 11.7 & 11.6 \\
jillo & White & 12.0 & 11.7 & 10.3 & 11.8 & 12.0 & 12.1 & 11.0 \\
& Chocolate & 10.6 & 10.0 & 11.5 & 11.9 & 10.8 & 11.0 & 11.1 \\
Group III, fed im- & 1940 & 13.0 & 13.1 & 14.0 & 13.3 & 13.2 & 13.0 & 13.5 \\
ported hay & 1966 & 11.6 & 12.0 & 11.2 & 13.6 & 12.3 & 13.0 & 12.8 \\
& 1949 & 11.9 & 12.1 & 12.8 & 13.6 & 13.8 & 14.8 & 13.9 \\
\hline
\end{tabular}

TABLE 2.-Packed-cell volume of blood of 10 differently fed goats taken at 15-day intervals, in Puerto Rico, 1953

\begin{tabular}{|c|c|c|c|c|c|c|c|}
\hline \multirow{2}{*}{ Group treatment } & \multirow{2}{*}{ Goat No. or name } & \multicolumn{6}{|c|}{ Volume of packed-cells, Wintrobe method, on- } \\
\hline & & June 16 & June 30 & July 13 & July 27 & Aug. 12 & Aug. 24 \\
\hline \multirow{4}{*}{ Group I, fed Merker } & 1987 & 29.0 & 28.1 & 27.6 & 30.0 & 31.3 & 28.6 \\
\hline & 1959 & 32.2 & 33.3 & 31.4 & 33.8 & 35.4 & 34.5 \\
\hline & 1963 & 33.8 & 32.0 & 30.7 & 32.4 & 31.3 & 29.8 \\
\hline & 1982 & 37.0 & 34.8 & 36.7 & 37.0 & 34.3 & 33.3 \\
\hline \multirow{4}{*}{$\begin{array}{l}\text { Group II, fed malo- } \\
\text { jillo }\end{array}$} & 1942 & 33.2 & 33.2 & 32.6 & 33.0 & 32.8 & 31.3 \\
\hline & White & 31.3 & 29.8 & 32.0 & 32.8 & 33.8 & 34.0 \\
\hline & Chocolate & 29.0 & 32.3 & 33.0 & 31.0 & 31.7 & 30.8 \\
\hline & 1940 & 37.5 & 38.4 & 38.2 & 38.0 & 38.4 & 37.0 \\
\hline \multirow{2}{*}{$\begin{array}{l}\text { Group III, fed im- } \\
\text { ported hay }\end{array}$} & 1966 & 33.8 & 32.6 & 39.0 & 35.0 & 38.7 & 35.0 \\
\hline & 1949 & 34.2 & 34.7 & 39.2 & 40.0 & 42.8 & 37.2 \\
\hline
\end{tabular}

animals had an abundant supply of fresh grass and concentrate. Packedcell-volume studies on the samples also failed to show any significant variation from the expected normal and the control animals (table 2).

Fecal examinations for nematode ova exhibited a somewhat well-defined picture of the progressive degree of parasitism of the experimental animals (table 3). The first ova detected, those of Strongyloides papillosus, were observed even before the start of the experiments, thus indicating once more that it is very difficult to prevent animals from acquiring $S$. papillosus 
TABLE 3.-Results of microscopical fecal examinations of 10 differently fed goats, - specimens taken at 15-day intervals, in Puerto Rico, 1953

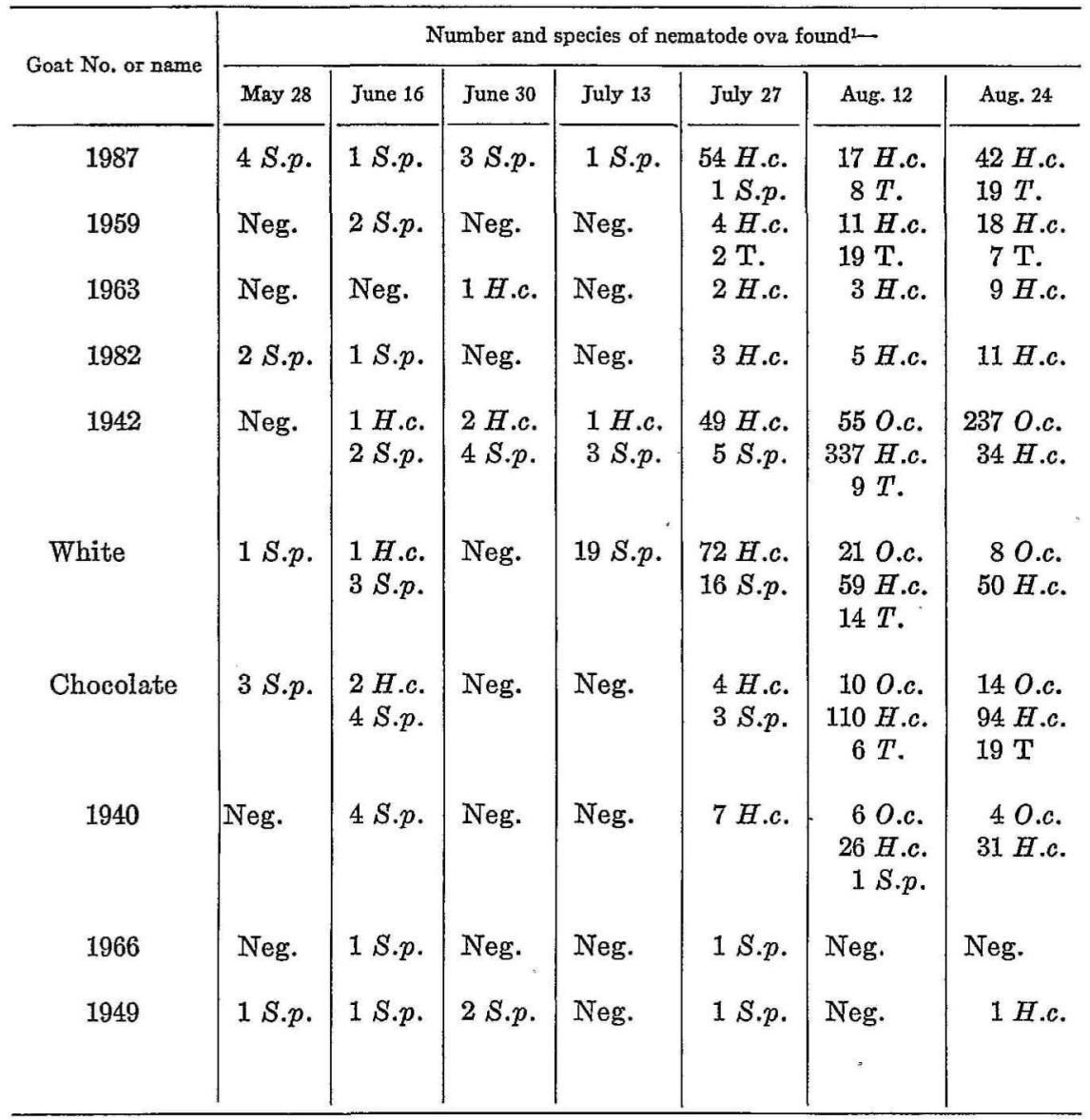

${ }^{1}$ S.p. = Strongyloides papillosus; H.c. = Haemonchus contortus; $T .=$ Trichostrongylus spp.; Neg. = no ova seen; O.c. = Oesophagostomum columbianum.

even when cared for meticulously (2). The infestations with this worm evidently disappeared about a month before the end of this work and they were not recovered from the digestive tracts of the animals after these were sacrificed.

Haemonchus contortus was the second parasite to be harbored by the goats. It was also the one found more often and consistently and in the largest number of the goats. Ova of these worms were observed a month after the beginning of the experiment. Trichostrongylus spp. ova were observed $21 / 2$ months after the start of the experiment, being followed 15 
days later by Oesophagostomum columbianum. Eggs of Trichostrongylus and $O$. columbianum were observed only after it was decided to obtain grass for the animals from the plots near the drainage ditch next to the barn.

Feces from those goats receiving malojillo (group II) (No. 1942, White, Chocolate, and No. 1940) showed a considerably larger number of ova than those in group I fed Merker grass (Nos. 1987, 1959, 1963, and 1982). The total number. of ova observed in the 28 fecal samples of the goats eating Merker grass was 250, or 8.9 eggs per gram of feces. The total number of eggs for the malojillo group was 1,351, or 48.2 eggs per gram of fecal sample. Only 8 eggs were observed in the 14 fecal samples obtained from the control animals, that is, 0.57 eggs per gram-sample. Therefore, animals of groups I and II exhibited a significantly larger number of ova than those of the control group.

After the goats were sacrificed, a very thorough examination of their digestive tracts, following the technique described under Materials and Methods, was performed. Three species of nematodes, Haemonchus contortus, Oesophagostomum columbianum, and Trichostrongylus axeii were recovered. No Strongyloides papillosus were observed. A specimen each of Thysanosoma actinioides and Moniezia expansa was recovered from goat No. 1987. Goat Chocolate had an immature specimen of $M$. expansa. (table 4).

One hundred and ninety-one nematodes were recovered from the four goats comprising group I, while 1,028 nematodes were recovered from the animals in group II. Only 3 nematodes were seen in one of the two goats in control group III. The number of worms recovered from the group eating malojillo was significantly larger than those from the other two groups. As a whole, the total number of worms found in all the animals was exceedingly low, but this may be explained by the fact that the chances for infestation through contamination were reduced to a minimum. The very low numbers of parasites recovered from the control animals, and the fluctuations in the numbers of ova and worms recovered from goats of the same group bear this out.

Goats supplied with malojillo grass had the largest number of nematode parasites. Only the animals in group II harbored Oesophagostomum columbianum. Haemonchus contortus was recovered from goats of all three groups.

Considering that all goats involved in this work received abundant, adequate feed, that the chances of contamination were reduced to a minimum, that the two grasses studied were obtained from the same habitat and handled identically, and that there was no opportunity for crosscontamination of one grass with larvae from the other, then it may be 
TABLE 4.-Number and species of intestinal parasites found on postmortem examination of 10 differently fed goats, Puerto Rico, 1953

\begin{tabular}{|c|c|c|c|}
\hline \multirow{2}{*}{ 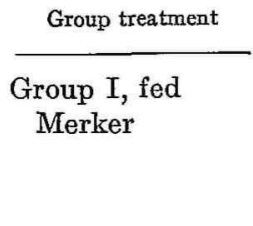 } & \multirow{2}{*}{$\begin{array}{c}\text { Goat No. or name } \\
1987\end{array}$} & \multicolumn{2}{|c|}{ Species and number of intestinal parasites recovered } \\
\hline & & $\begin{array}{l}\text { Haemonchus contortus } \\
\text { Thysanosoma actinioides } \\
\text { Trichostrongylus spp. } \\
\text { Moniezia expansa }\end{array}$ & $\begin{array}{r}17 \\
1 \\
42 \\
1\end{array}$ \\
\hline & 1959 & $\begin{array}{l}H . \text { contortus } \\
\text { Trichostrongylus spp. }\end{array}$ & $\begin{array}{l}67 \\
12\end{array}$ \\
\hline & 1963 & H. contortus & 8 \\
\hline & 1982 & do. & 43 \\
\hline $\begin{array}{l}\text { Group II, fed } \\
\text { malojillo }\end{array}$ & 1942 & $\begin{array}{l}\text { Oesophagostomum columbianum } \\
\text { H. contortus } \\
\text { Trichostrongylus spp. }\end{array}$ & $\begin{array}{r}13 \\
257 \\
32\end{array}$ \\
\hline & White & $\begin{array}{l}\text { O. columbianum } \\
\text { H. contortus } \\
\text { Trichostrongylus spp. }\end{array}$ & $\begin{array}{r}24 \\
285 \\
13\end{array}$ \\
\hline & Chocolate & $\begin{array}{l}\text { O. columbianum } \\
\text { H. contortus } \\
\text { Trichostrongylus spp. } \\
\text { M. expansa } a^{1}\end{array}$ & $\begin{array}{r}6 \\
213 \\
58 \\
1\end{array}$ \\
\hline & 1940 & $\begin{array}{l}\text { O. columbianum } \\
\text { H. contortus }\end{array}$ & $\begin{array}{r}3 \\
123\end{array}$ \\
\hline $\begin{array}{l}\text { Group III, fed } \\
\text { imported hay }\end{array}$ & $\begin{array}{l}1966 \\
1949\end{array}$ & (2) & 3 \\
\hline
\end{tabular}

${ }^{1}$ Immațure.

2 Negative.

concluded that goats receiving malojillo are more subject to a heavier infestation with nematode larvae than those receiving Merker grass.

\section{SUMMARY}

1. The degree of nematode larvae infestation in goats fed malojillo (Pará grass) and Merker grass in Puerto Rico was investigated in an attempt to determine whether goats would become more significantly parasitized when eating either one of the two grasses. 
2. The technique of raising and-maintaining parasite-free animals is described.

3. Blood samples for hemoglobin and packed-cell determinations and fecal samples for nematode ova counts were obtained every 15 days from the 10 experimental goats.

4. It was found that goats eating malojillo harbored a larger number of nematode parasites than those eating Merker grass. Ova of Strongyloides papillosus appeared in the feces of the goats even before the beginning of this work, but that infestation disappeared about a month before the end of the experiment. Haemonchus contortus ova were seen next, being followed chronologically by Trichostrongylus spp. and Oesophagostomum columbianum. The latter species was harbored only by the goats receiving malojillo. Goats eating Merker grass exhibited 8.9 ova per gram of fecal sample throughout the experiment, those receiving malojillo showed 48.2 eggs per sample, while those in the control group had only 0.57 eggs per sample.

5. All animals were sacrificed at the conclusion of this work and the digestive tracts thoroughly searched for helminths. More nematodes were secured from the goats eating malojillo than from the other two groups. A total of 1,028 nematodes was recovered from animals in the malojillo group, 191 from the Merker group, and only 3 from the control group receiving imported hay.

\section{RESUMEN}

1. Se investigó sobre si el grado de infestación de las yerbas malojillo y Merker con larvas de nemátodos podría ser un factor significativo en cuanto a la mayor o menor parasitación de cabros, al alimentarse con una $\mathrm{u}$ otra de estas yerbas infestadas.

2. Se describe la técnica que debe practicarse para criar cabros libres de infestación parasitaria.

3. El contaje de los huevecillos de nemátodos endoparasíticos en las muestras fecales y la determinación de hemoglobina y volumen eritrocítico de la sangre se hicieron cada 15 días, incluyendo a cada uno de los 10 cabros experimentales.

4. Se encontró que los cabros alimentados con yerba malojillo infestada tuvieron un número mayor de nemátodos parasíticos que los alimentados con yerba Merker. En la etapa pre-experimental aparecieron los huevecillos del Strongyloides papillosus, los cuales desaparecieron aproximadamente un mes antes de terminarse el experimento. En orden sucesivo fueron apareciendo, según los exámenes coprológicos, los huevecillos de otros nemátodos, tales como Haemonchus contortus, Trichostrongylus spp. y Oesophagostomum columbianum. Esta última especie sólo apareció en los cabros que consumieron yerba malojillo. 
El contaje promedio de los huevecillos de las diferentes especies de endoparásitos, por gramo de materia fecal examinada microscópicamente, fué de 8.9, con respecto a los cabros alimentados con yerba Merker. Este mismo contaje hecho a cabros alimentados con yerba malojillo alcanzó un promedio de 48.2. Los animales del grupo testigo, alimentados con heno importado, al someterse al contaje, sólo tuvieron un promedio de 0.57 huevecillos por gramo de materia fecal examinada. .

5. Se sacrificaron todos los cabros experimentales cuando se terminó el experimento y al hacerse los exámenes de sus tractos digestivos se encontró que los cabros alimentados con yerba malojillo tuvieron más nemátodos que los de los otros tratamientos. Se recobraron 1,028 nemátodos parasíticos de los cabros alimentados con yerba malojillo; 191 de los alimentados con yerba Merker y 3 de los animales testigos alimentados con heno importado.

\section{LITERATURE CITED}

1. Hoffman, W. S., Photelometric Clinical Chemistry, p. 56, William Morrow \& Co., New York, N. Y., 1941.

2. Morgan, B. B., and Hawkins, P. A., Veterinary Helminthology, Burgoss Publishing Co., Minneapolis, Minn., 1949.

3. Stitt, E. R., Clough, P. W., and Branham, S. E., Practical Bacteriology, Hematology, and Parasitology, 10th. edition, p. 648, The Blakiston Co., Philadelphia, Pa., 1948. 